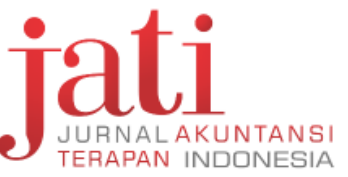

Jati: Jurnal Akuntansi Terapan Indonesia Vol 1 No 2 Hal 70-81 Oktober 2018

\title{
Studi Konsistensi Perencanaan dan Penganggaran Daerah Bidang Pariwisata di Kabupaten Gunungkidul
}

http://journal.umy.ac.id/index.php/jati C) 2018 JATI. All rights reserved DOI: 10.18196/jati.010208

\section{DATA ARTIKEL:}

Diterima: 7 Agt 2018

Direviu: 8 Okt 2018

Direvisi: 10 Okt 2018

Disetujui: 19 Okt 2018

TOPIK ARTIKEL:

Akuntansi Sektor Publik

ABSTRAK: Penelitian ini dilakukan untuk menganalisis tingkat konsistensi dokumen perencanaan dan penganggaran, yaitu pada RPJMD, RKPD, Renstra, Renja, PPAS dan DPA SKPD. Penelitian ini bertujuan untuk mengidentifikasi faktor-faktor yang mempengaruhi konsistensi perencanaan dan penganggaran serta untuk mengetahui upaya yang telah dilakukan untuk meningkatkan konsistensi perencanaan dan penganggaran. Penelitian ini menggunakan metode kualitatif dengan pendekatan studi kasus di bidang Pariwisata pada Dinas Kebudayaan dan Kepariwisataan Kabupaten Gunungkidul. Partisipan dalam penelitian ini adalah pejabat atau pegawai yang terlibat dalam proses perencanaan dan penganggaran. Hasil penelitian menunjukkan bahwa tingkat konsistensi RKPD dan DPA bidang Pariwisata Dinas Kebudayaan dan Kepariwisataantahun 2015 sebesar 53,24\% (cukup) dan tahun 2016 sebesar 63,54\% (cukup). Faktor-faktor yang mempengaruhi konsistensi perencanaan dan penganggaran yaitu kurangnya pemahaman tentang perencanaan dan penganggaran, SKPD belum memperhatikan pagu indikatif dan indikator kinerja, intervensi politik anggota DPRD, kebijakan Pemerintah Pusat/Provinsi, komitmen pemangku kepentingan, pengambil kebijakan dan pelaksana kegiatan, dan proses manual dalam perencanaan.Upaya yang telah dilakukan untuk meningkatkan konsistensi perencanaan dan penganggaranantara lain: Inovasi PIWK, Desk Renja oleh Bappeda, Desk RKA oleh Tim Anggaran, Evaluasi Internal oleh Bappeda, Pengawasan oleh Inspektorat Daerah dan konsultasi dan evaluasi Gubernur.

\section{Kata Kunci: Konsistensi, Perencanaan, Penganggaran, Pagu Indikatif}

ABSTRACT: This study was conducted to determine the level of consistency between planning and budgeting documents, namely RPJMD, RKPD, strategic planning, Renja, PPAS and DPA SKPD. This study also aims to identify the factors that affect the consistency between planning and budgeting as well as to know the efforts that have been made to improve the consistency between planning and budgeting. This study used a qualitative method with a case study approach on tourism sector in the Culture and Tourism Office of Gunungkidul Regency. Participants in this study are officers or employees involved in the planning and budgeting process. The results showed that the level of consistency of RKPD and DPA the culture and Tourism Office in 2015 amounted to 53,24\% (satisfactory) and in 2016 amounted to $63,54 \%$ (good). Factors that affect the consistency, between the planning and budgeting are the lack of understanding of planning and budgeting: SKPDs' dis-regard of the indicative ceiling and performance indicators, political intervention by legislators, policy of Central/Provincial Government, commitment of stake-holders, policy makers and executors, and the manual processes in planning. Efforts that have been made to improve the consistency of between planning and budgeting are, among others: PIWK innovation, work plan desk by BAPPEDA desk, RKA desk by the budget team, internal evaluation by Bappeda, supervision by the Regional Inspectorate office and consulting and evaluation by the Governor.

\section{Keywords: Consistency, Planning, Budgeting, Indicative Ceiling}

\section{SITASI ARTIKEL:}

Wasana, S. \& Halim, A. (2018). Studi Konsistensi Perencanaan dan Penganggaran Daerah Bidang Pariwisata di Kabupaten Gunungkidul, Jati: Jurnal Akuntansi Terapan Indonesia, 1(2), 70-81. 


\section{PENDAHULUAN}

Perencanaan mempunyai peran yang sangat penting dalam mewujudkan tujuan pembangunan baik di tingkat nasional maupun di daerah. Keberhasilan pembangunan di suatu wilayah pemerintahan dipengaruhi oleh kualitas perencanaan tersebut disusun. Perencanaan pembangunan akan memberikan arah yang jelas terhadap pembangunan disuatu wilayah apabila disusun dengan target yang jelas dan terukur sehingga memudahkan pemerintah dalam mencapai tujuan yang telah ditetapkan. Dalam perencanaan pembangunan di daerah, pemerintah daerah memiliki kewenangan yang lebih besar dengan adanya otonomi daerah. Kewenangan dan tanggungjawab yang besar ini diharapkan mendorong daerah untuk dalam meningkatkan kemampuan keuangan daerah dengan menggali dan meningkatkan potensi yang dimiliki dan juga melakukan inovasi kebijakan untuk mendukung pembangunan daerah.

Perencanaan daerah tahunan akan dituangkan dalam Anggaran Pendapatan dan Belanja Daerah (APBD) ialah Rencana Kerja Pemerintah Daerah atau disingkat RKPD. Menurut Undang-Undang Nomor 17 Tahun 2003 dijelaskan bahwa dalam proses penyusunan APBD sampai di-tetapkannya, berpedoman pada rencana kerja pemerintah daerah. Proses penyusunan perencanaan daerah dilakukan melalui musyawarah peren-cananaan pembangunan daerah. MenurutUndang-Undang Nomor 25 Tahun 2004 tentang Sistem Perencaanaan Pembangunan Nasional, musyawarah perencananaan pembangunan adalah forum antarpelaku dalam rangkamenyusun rencana pem-bangunan nasional dan rencana pembangunan daerah. Musrenbang dilaksanakan untuk menyusun Rencana Pembangunan Jangka Panjang Daerah (RPJPD), Rencana Pembangunan JangkaMenengah Daerah (RPJMD) dan Rencana Kerja Pemerintah Daerah (RKPD).

Dalam pasal 129 ayat 3 Undang-Undang Nomor 25 Tahun 2004 disebutkan bahwa RKPD digunakansebagai landasan penyusunan KUA dan PPAS dalam rangka penyusunan RAPBD. Konsistensi antara perencanaan dan penganggaran penting untuk diperhatikan karena merupakan indikator dalam menilai kinerja pemerintah. Hal ini telah dijelaskan pasal 4 ayat (2) dalam Undang-Undang Nomor 25 Tahun 2004 bahwa sistem perencanaan pembangunan nasional bertujuan untuk menjamin keterkaitan dan konsistensi antara perencanaan dan penganggaran, pelaksanaan dan pengawasan. Dokumen perencanaan juga harus memiliki keterkaitan antara yang satu dengan yang lain untuk menjamin keberlanjutan pembangunan serta mempertahankan dan meningkatkan prestasi pembangunan yang telah dicapai didaerah.

Proses perencanaan pembangunan di Kabupaten Gunungkidul telah dilakukan melalui mekanisme musrenbang sebagaimana kabupaten lain di Indonesia. Melalui musrenbang masyarakat dapat berpartisipasi dan menyampaikan usulan secara berjenjang. Beberapa permasalahan dalam proses perencanaan dan penganggaran partisipasi antara lain menurut Suhirman (Buletin Lesung edisi III/ 2005) dalam Bastian, 2006: (1) masih terjadinya dualisme yaitu perencanaan (melibatkan masyarakat) dengan proses penganggaran (kewenangan pemerintah) sehingga menyebabkan usulan yang disepakati dalam perencanaan tereduksi dalam proses penganggaran; (2) tidak ada informasi yang memadai tentang prioritas dan perkiraan alokasi anggaran (pagu indikatif) sehingga menyebabkan meningkatnya usulan dalam perencanaan partisipasi; (3) masih terjadinya asimetri antara perencanaan dan anggaran pembangunan dengan permasalahan yang dihadapi masyarakat. Perumpamaan dalam hal ini adalah "yang direncanakan lain dengan yang dianggarkan dari daerah".

Pembangunan di bidang pariwisata menjadi salah satu fokus utama di Kabupaten Gunungkidul. Hal ini terlihat padadari visi Kabupaten Gunungkidul Tahun 2016-2021 yaitu “Mewujudkan Gunungkidul Sebagai Daerah Tujuan Wisata Terkemuka dan Berbudaya Menuju Masyarakat Yang Berdaya Saing Maju, Mandiri dan Sejahtera 2021". Disamping hal itu di Kabupaten Gunungkidul bidang pariwisata juga mengalami peningkatankunjungan wisatawan selama 4 tahun terakhir. Pada empat tahun terakhir terjadi peningkatan jumlah wisatawan yang berkunjung ke obyek wisata di Kabupaten Gunungkidul. Jumlah kunjungan wisata tersebut dapat dilihat pada Tabel 1.

Pemerintah Kabupaten Gunungkidul melalui Badan Perencanaan dan Pembangunan Daerah (Bappeda) telah melakukan inovasi dalam perencanaan pembangunan daerah. Inovasi tersebut yaitu dengan diterapkannya pagu indikatif. Kabupaten Gunungkidul menerapakan pagu indikatif pada tahun 2012 dengan diterbitkannya Peraturan Daerah Nomor 18 Tahun 2012 tentang Tata Cara Penyusunan Rencana Pembangunan Daerah dan Pelaksanaan Musyawarah Pembangunan Daerah. Kemudian untuk penentuan pagu indikatif diatur dengan Peraturan Bupati Nomor 40 Tahun 2012 tentang Tata Cara Perhitungan Pagu Indikatif Wilayah Kecamatan dan Penyusunan Program Pembangunan Prioritas. Pemerintah Kabupaten Gunungkidul merupakan salah satu kabu- 
Tabel 1. Jumlah Kunjungan Wisatawan di Kabupaten Gunungkidul Tahun 2012-2015

\begin{tabular}{ccccc}
\hline Wisatawan & \multicolumn{5}{c}{ Tahun } \\
\cline { 2 - 5 } & 2012 & 2013 & 2014 & 2015 \\
Asing & 3.508 & 5.772 & 4.228 & 4.125 \\
Domestik & 1.171 .735 & 1.771 .980 & 2.030 .257 & 2.642 .759 \\
Jumlah & 1.175 .243 & 1.771 .980 & 2.030 .257 & 2.642 .759 \\
\hline
\end{tabular}

Sumber: Disbudpar Gunungkidul 2015

Tabel 2. Evaluasi Kesesuaian Program dalam Renja SKPD terhadap RKPD, dan Renstra SKPD terhadap RPJMD Th.2016

\begin{tabular}{clc}
\hline No. & \multicolumn{1}{c}{ Nama SKPD } & Persentase 2016 \\
\hline 1 & Sekretariat DPRD & 99 \\
2 & Badan Perencanaan Pembangunan Daerah & 100 \\
3 & Badan Pemberdayaan Masyarakat, Perempuan, dan KB & 80 \\
4 & Dinas Kebudayaan dan Kepariwisataan & 76,15 \\
\hline
\end{tabular}

Sumber: Bappeda Gunungkidul 2016

paten yang mendapatkan penghargaan nasional yaitu Pangripta Nusantara tahun 2014 sebagai kabupaten dengan perencanaan daerah terbaik pertama untuk kategori B. Sebagai daerah yang telah mendapat penghargaan Kabu-paten Gunungkidul sering mendapat kunjungan studi banding tentang perencanaan daerah dan kabupaten lain. Namun berdasarkan data monitoring dan evaluasi (e-monev) masih terdapat beberapa SKPD yang ditengarai masih belum konsisten dalam hal keterkaitan dokumen perencanaan dan penganggaran. Hal ini dapat dilihat pada Tabel 2 .

Berdasarkan uraian tersebut, maka penelitian ini akan meneliti pada bidang Pariwisata di Dinas Kepariwisataan dan Kebudayaan karena SKPD tersebut tingkat konsistensi program pada dokumen Renja SKPD terhadap RKPD, dan Renstra SKPD terhadap RPJMD tahun 2016 masih sebesar 76,15 persen. Hal ini menunjukkan konsistensi dokumen perencanaan dan penganggaran ditengarai belum optimal.

Beberapa studi yang membahas masalah konsistensi perencanaan dan penganggaran antara lain Fitry (2012), yang meneliti konsistensi perencanaan dan penganggaran daerah bidang kesehatan kota Lubuk Linggau tahun 2010. Hasil penelitian menunjukkan bahwa tingkat konsistensi perencanaan dan penganggaran bidang kesehatan di Kota Lubuklinggau masih kurang baik yakni sebe-sar 58,82\% untuk analisis konsistensi DPA tahun 2010 terhadap RPJMD 2008-2013. Sugiarto dan Mutiarin (2016) melakukan penelitian tentang konsistensi perencanaan pembangunan daerah dengan anggaran daerah pada bidang fisik dan prasarana tahun 2013-
2015 di Kabupaten Gunungkidul. Hasil penelitian menunjukkan bahwa tingkat konsistensi selama tiga tahun dari tahun 2013, 2014, 2015 pada bidang fisik dan prasarana ada peningkatan. Hasil penelitian menunjukkan bahwa tingkat konsistensi selama tiga tahun dari tahun 2013, 2014, 2015 pada bidang fisik dan prasarana ada peningkatan. Pada SKPD DPU tahun 2013 sebesar 77\%, dan tahun 2015 sebesar 96\%. Pada SKPD Dishubkominfo tahun 2013 sebesar 93\%, dan tahun 2015 sebesar 94\%. Kemudian untuk SKPD Kapedal tahun 2013 sebesar 88\%, tahun tahun 2015 sebesar $100 \%$. Faktor-faktor yang memengaruhi konsistensi perencanaan dengan penganggaran daerah yaitu pemahaman antara SKPD, Bappeda, DPPKAD, TAPD serta DPRD dalam menjabarkan program dan kegiatan pada SKPD; adanya kebijakan pusat; adanya hasil evaluasi oleh Gubernur; terwadahinya pokok-pokok pikiran DPRD ke dalam program kegiatan SKPD.

Kumalasari (2016) melakukan penelitian yang lebih luas tentang analisis konsistensi antara dokumen RKPD, PPAS serta APBD pada pemerintah Kota Magelang. Hasil analisis data ditemukan bahwa proses perencanaan dan penganggaran pada pemerintah Kota Magelang masih terdapat inkonsistensi pada tahun 2014 dan tahun 2015. Faktorfaktor yang menyebabkan terjadi inkonsistensi adalah rendahnya pemahaman tentang perencanaan dan penganggaran baik dari eksekutif, legislatif maupun masyarakat, intervensi DPRD, kurangnya komitmen bersama dari pemangku kepentingan dan pengambil kebijakan, penggunaan aplikasi yang berbeda, belum adanya sanksi yang jelas apabila terjadi inkonsistensi, kurangnya perhatian terhadap konsistensi indikator kinerja, 
serta kebijakan dari pemerintah pusat yang seringkali terlambat.

Berbeda dengan penelitian sebelumnya penelitian ini menganalisis tingkat konsistensi pada dokumen jangka pendek tapi juga dokumen jangka menengah pada bidang pariwisata Kabupaten Gunungkidul tahun 2015-2016. Penelitian bertujuan untuk mengidentifikasi faktor-faktor yang mempengaruhi konsistensi perenanaan dan penganggaran. Peneltian ini juga mengeksplorasi tentang upaya apa saja yang telah dilakukan untuk meningkatkan konsistensi perencanaan dan penganggaran di kabupaten Gunungkidul. Adapun pemilihan obyek dilakukan di Kabupaten Gunungkidul karena pernah mendapatkan penghargaan Pangripta Nusantara sebagai Kabupaten dengan perencanaan terbaik nasional untuk kategori B di tahun 2014, namun berdasarkan data monev tahun 2016 ada beberapa SKPD yang belum optimal konsistensinya yaitu di Dinas Kebudayaan dan Kepariwisataan program pada dokumen Renja SKPD terhadap RKPD, dan Renstra SKPD terhadap RPJMD Th.2016 yakni sebesar 76,15 persen.

Penelitian ini diharapkan memberikan manfaat secara praktis diharapkan dapat: (1) memberikan masukan atau pertimbangan dalam penyempurnaan kebijakan dalampenyusunan rencana pembangunan daerah sehingga dapat mengurangi permasalahan yang harus dihadapi; (2) mengetahui keberhasilan usulan program kegiatan yang masuk dalam APBD; (3) mengetahui tingkat konsistensi dokumen perencanaan dan penganggaran. Secara akademis penelitian ini diharapkan dapat dijadikan sebagai referensi bagi peneliti lain yang ingin melakukan penelitian yang serupa maupun yang akan melanjutkan penelitian ini.

\section{METODE PENELITIAN}

Penilitian ini akan menggunakan metode kualitatif dengan pendekatan studi kasus. Penelitian ini akan menggunakan desain kasus tunggal untuk menganalisis konsistensi perencanaan dan penganggaran daerah bidang pariwisata pada Dinas Kebudayaan dan Kepariwisataan Kabupaten Gunungkidul.

Data ataupun informasi yang didapat dari penelitian ini sebagian besar merupakan data kualitatif. Partisipan yang terkait dengan masalah penelitian ini adalah orang-orang kunci yang menangani proses perencanaan dan penganggaran yakni berasal dari: Dinas Kebudayaan dan Kepariwisataan, Bappeda, dan Badan Keuangan dan Aset Daerah. Data sekunder dari instansi antara lain: RPJMD, Renstra SKPD, Renja SKPD, RKPD, KUA PPAS dan DPA SKPD.
Dalam pengumpulan data untuk penelitian ini menggunakan penelitan dokumen, wawancara dan penelitian kepustakaan. Sesuai dengan permasalahan, jenis penelitian kualitatif dan sumber data yang digunakan maka peneliti menggunakan triangulasi dalam pengumpulan data yaitu menggabungkan dari berbagai teknik pengumpulan data. Pengumpulan data dilakukan dengan triangulasi sumber data yaitu memperoleh data dari berbagai sumber yang berbeda dengan teknik yang sama. Dengan teknik triangulasi diharapkan akan didapat data yang lebih valid (Creswell, 2014).

Peneliti melakukan pengecekan dan pemilihan terhadap dokumen-dokumen yang diperoleh terkait dengan perencanaan dan penganggaran pada Dinas Kebudayaan dan Kepariwisataan di Kabupaten Gunungkidul tahun 2015-2016. Dokumen tersebut antara lain: RPJMD, Renstra SKPD, Renja SKPD, RKPD, PPAS, APBD dan dokumen terkait lainnya. Dokumen tersebut kemudian dianalisis menggunakan matrik konsolidasi dan dilakukan penilaian.

Wawancara ini dilakukan dengan partisipan kunci yang telah dipilih dan dilakukan secara terbuka namun tetap mendalam sesuai alur wawancara. Partisipan yang rencanaya akan di wawancarai adalah orang-orang kunci yang mengetahui dari proses musrenbang, perencanaan di tingkat SKPD, penyusunan RKPD, penyusunan RAPBD/APBD dan proses review oleh Inspektorat Daerah.

Penelitian kepustakaan dilakukan dengan cara mempelajari teori-teori dari buku-buku teks, bahan-bahan kuliah, jurnal dan artikel yang terkait dengan masalah yang diteliti. Penelitian kepustakaan ini bertujuan untuk memperoleh teori dan konsep sesuai dengan masalah yang diteliti sehingga menjadi suatu landasan teori dalam penyusunan penelitian.

\section{Analisis dan Interpretasi Data}

Analisis dilakukan secara simultan, berulang dan berkelanjutan dengan memproses dan menyiapkan data yang telah didapatkan, lalu data tersebut dideskripsikan, dibandingkan, dikategorikan, dikonseptualisasikan, dan dijelaskan sehingga dapat membangun suatu teori dari hasil penelitian (Hennink, Hutter dan Bailey, 2012: 238). Dalam melakukan analisis dari teks atau gambar yang banyak, tidak semua informasi akan digunakan. Oleh karena itu perlu dilakukan pemisahan data dan memfokuskan pada sebagian data khususnya dalam menjawab pertanyaan penelitian dan mengabaikan yang lainnya.

Untuk menjawab terkait seberapa tingkat konsistensi perencanaan dan penganggaran dila-kukan dengan menganalisis dan membandingkan nomenklatur program dan kegiatan pada dokumen peren- 
canaan dan penganggaran dengan menggu-nakan matrik konsolidasi. Proses tersebut dilakukan dengan menganalisis dokumen perencanaan dan penganggaran dengan membandingkan antara lain: (1) RPJMD dengan Renstra SKPD (Pasal 84 Permendagri 54/2010); (2) Renstra SKPD dengan Renja SKPD (Pasal 97 Permendagri 54/2010); (3) RKPD dengan PPAS (Pasal 129 Permendagri 54/2010); dan (4) RKPD dengan DPA SKPD (Pasal 17 UU 17/2003).

Setelah itu, dilakukan scoring atau penilaian dengan memperhatikan konsistensi dari kriteria yang digunakan. Metode yang akan digunakan dalam penilaian ini mengadopsi dari Permenpan-RB Nomor 25 Tahun 2012 jo Permenpan-RB Nomor 20 Tahun 2013 tentang Petunjuk Pelaksanaan Evaluasi Akuntabilitas Kinerja Intsansi Pemerintah karena didalamnya juga menilai keterkaitan komponenkomponen perencanaan kinerja dengan penganggaran (Kumalasari, 2016). Metode penilaian tersebut dapat dijelaskan sebagai berikut:

Dokumen 5 tahun ke dokumen 1 tahun. Apabila nomenklatur program sama maka diberi nilai 1 dan apabila nomenklatur tidak sama diberi nilai 0 .

Dokumen tahunan. Untuk dokumen tahunan dengan ketentuan (1) apabila nomenklatur kegiatan sama diberi nilai 0,5 , apabila tidak sama diberi nilai o. (2) apabila indikator kinerja output konsisten diberi nilai 0,25 (3) apabila apabila indikator kinerja input (pagu indikatif) dan indikator kinerja output konsisten diberi nilai 0,5 (3) apabila keduanya tidak konsisten diberi nilai o. (Kumalasari, 2016)

Dari uraian tersebut akan diketahui nilai untuk konsistensi program/kegiatan maupun indikator kinerja dengan nilai maksimal adalah 1 (satu). Setelah diperoleh nilai untuk masing-masing item kemudian dijumlahkan untuk mencari total score yang selanjutnya digunakan untuk menghitung tingkat konsistensi. Konsistensi program/ kegiatan dihitung dengan membanding-kan jumlah score yang diperoleh dengan jumlah score maksimal kali $100 \%$.

Konsistensi Program $/$ Kegiatan $=\frac{\text { Score yg diperoleh } \times 100 \%}{\text { Jumlah score maksimal }}$

Setelah didapatkan persentase konsistensi dan dilakukan penjumlahan tingkat konsisten untuk SKPD, selanjutnya hasil dari SKPD tersebut dinterpretasikan berdasarkan kategori menurut Permenpan RB Nomor 25 Tahun 2012. Setelah melakukan analisis dokumen tersebut, langkah berikutnya adalah melakukan tinjauan lapangan untuk melakukan wawancara. Wawancara dimaksudkan untuk mengkroscek hasil analisis yang dilakukan agar menjadi lebih valid.

\section{HASIL DAN PEMBAHASAN}

\section{Gambaran Dokumen dan Partisipan}

Pengumpulan data dalam penelitian ini menggunakan dokumen dan wawancara mendalam kepada orang-orang yang terlibat langsung dalam perencanaan dan penganggaran. Dokumen dalam penelitian ini didapatkan dari Badan Perencanaan dan Pembangunan Daerah, Dinas Pariwisata, Badan Keuangan dan Aset Daerah Kabupaten Gunungkidul. Dokumen tersebut meliputi: RPJMD tahun 2010-2015 dan RPJMD tahun 2016-2021; RKPD tahun 2015 dan tahun 2016; Renstra Dinas Kebudayaan dan Kepariwisataan tahun 2010-2015 dan Renstra tahun 2016-2021; Renja Kebudayaan dan Kepariwisataan tahun 2015 dan tahun 2016; KUA-PPAS Pemerintah Kabupaten Gunungkidul tahun 2015 dan tahun 2016; DPA Dinas Kebudayaan dan Kepariwisataan tahun 2015 dan tahun 2016.

Data primer di dapatkan dari hasil wawancara mendalam terhadap 10 orang partisipan dari Dinas Pariwisata 1 orang, Bappeda 5 orang, BKAD 1 orang, Inspektorat Daerah 1 orang, anggota DPRD 1 orang. Kriteria yang digunakan dalam pemilihan partisipan adalah mereka yang memahami proses perencanaan dan penganggaran dan terlibat langsung di dalamnya baik dari pelaksana, pengawas dan legislatif pada tahun 2015-2016. Pembahasan dalam penelitian ini akan fokus pada bidang pariwisata karena itu bidang kebudayaan tidak dilakukan pembahasan dalam penelitian ini. Pembahasan bab ini terbagi menjadi tiga tahap, Tahap pertama menganalisis seberapa tingkat konsistensi dokumen perencanaan dan penganggaran, tahap kedua menguraikan tentang faktor-faktor yang mempengaruhi konsistensi antara perencanaan dan penganggaran. Kemudian yang ketiga tentang upaya yang dilakukan oleh pemerintah daerah dalam menjaga konsistensi antara perencanaan dan penganggaran.

\section{Analisis Tingkat Konsistensi Perencanaan dan Penganggaran di Bidang Pariwisata}

Analisis konsistensi akan dilakukan dengan membandingkan antara dokumen RPJMD dan Renstra, RKPD dan PPAS, dan RKPD dan DPA untuk tahun 2015-2016. Analisis ini dilakukan dengan memberikan skor nilai pada masing-masing program atau kegiatan maksimal 1 dan minimal 0 . Khusus untuk dokumen RPJMD dan renstra peneliti hanya dapat melakukan skoring pada nomenklatur program saja karena dalam dokumen tidak tersedia indikator kinerja dari setiap program. 


\section{Analisis Tingkat Konsistensi Dokumen RPJMD dan Renstra}

Analisis dokumen RPJMD dan renstra dilakukan guna mengetahui konsistensi dari kebijakan program yang ada di tingkat Pemerintah Kabupaten dengan dokumen renstra yang ada di Dinas Kebudayaan dan Kepariwisataan khususnya pada bidang pariwisata. Analisis dilakukan untuk dokumen RPJMD dan renstra tahun 2010-2015 dan 2016-2021.

Dalam dokumen RPJMD 2010-2015 pada tahun 2015 memuat 8 program sedangkan pada renstra Disbudpar memuat 9 program, ada 1 program yang ada di renstra namun tidak ada dalam RPJMD. Dokumen RPJMD dan renstra 2016-2021 pada tahun 2016 sama-sama memuat 10 program. Jadi tingkat konsistensi program pada dokumen RPJMD dan Renstra ditunjukkan dengan hasil Tingkat konsistensi RPJMD dengan Renstra Disbudpar 2010-2015 sebesar 88,89\% (kategori sangat baik) dan Tingkat konsistensi RPJMD dengan Renstra Disbudpar 2016-2021 naik menjadi sebesar 100\% (kategori memuaskan).

Hal ini menunjukan bahwa dokumen RPJMD telah menjadi acuan dalam penyusunan dokumen Renstra pada Dinas Kebudayaan dan Kepariwisatan pada tahun 2015 dan tahun 2016.

\section{Analisis Tingkat Konsistensi Dokumen Renstra dan Renja Tahun 2015-2016}

Analisis ini dilakukan guna mengetahui konsistensi dari kegiatan pada dokumen renstra dengan renja di tingkat SKPD.Analisis dilakukan dengan membandingkan dokumen renstra dan renja Disbudpar tahun 2010-2015 dan 2016-2021. Hasil analisis dapat ditunjukkan pada tabel 3.
Dari analisis tersebut tingkat konsistensi dokumen renstra dengan renja tahun 2015 termasuk tinggi yaitu untuk program sebesar 91,67\% dan kegiatan 85,71\%, sedang tahun 2016 mengalami kenaikan menjadi untuk program sebesar $100 \%$ dan kegiatan sebesar 97,87\%. Hal ini menunjukan bahwa dokumen Renstra telah digunakan sebagai acuan untuk penyusunan dokumen renja SKPD.

\section{Analisis Tingkat Konsistensi Dokumen RKPD dan PPAS Tahun 2015-2016}

Sebagaimana dijelaskan dalam Permendagri 54/2010 dokumen RKPD menjadi acuan untuk penyusunan dokumen PPAS dan APBD dalam hal ini DPA.Untuk melihat apakah dokumen tersebut sudah dijadikan acuan atau belum perlu dilakukan analisis. Analisis dokumen dilakukan untuk mengetahui tingkat konsistensi kegiatan antara dokumen RKPD dengan PPAS bidang pariwisata tahun 20152016, yang ditampilkan pada tabel 4 .

Dari analisis tersebut tingkat konsistensi dokumen PPAS terhadap RKPD tahun 2015 termasuk cukup yaitu sebesar 52,31\%. Hal ini menunjukan bahwa dokumen RKPD belum sepe-nuhnya digunakan sebagai acuan. Tingkat konsis tensi PPAS terhadap RKPD pada tahun 2016 mengalami kenaikan menjadi sebesar $100 \%$ atau kategori memuaskan. Hal ini menunjukkan bahwa dokumen RKPD telah dijadikan acuan untuk penyusunan PPAS.

\section{Analisis Tingkat Konsistensi Dokumen RKPD dan DPA Tahun 2015-2016}

Sebagaimana dijelaskan pada UndangUndang Nomor 17 Tahun 2003 bahwa Anggaran Pendapatan dan Belanja Daerah dalam proses penyusunan sampai ditetapkannya, berpedoman pada

Tabel 3. Score Konsistensi Kegiatan Renstra dengan Renja

\begin{tabular}{ccccccc}
\hline No. & Tahun & $\begin{array}{c}\text { Jml.Prog/ } \\
\text { Keg. Renstra }\end{array}$ & $\begin{array}{c}\text { Jml. Prog/ } \\
\text { Keg. Renja }\end{array}$ & $\begin{array}{c}\text { Prog/Keg. } \\
\text { konsisten }\end{array}$ & $\begin{array}{c}\text { Persentase } \\
\text { Program }\end{array}$ & $\begin{array}{c}\text { Persentase } \\
\text { Kegiatan }\end{array}$ \\
\hline 1. & 2015 & $11 / 63$ & $12 / 56$ & $11 / 54$ & $91,67 \%$ & $85,71 \%$ \\
2. & 2016 & $10 / 47$ & $10 / 47$ & $10 / 46$ & $100,00 \%$ & $97,87 \%$ \\
\hline
\end{tabular}

Tabel 4. Score Konsistensi Kegiatan RKPD dengan PPAS

\begin{tabular}{|c|c|c|c|c|c|c|c|c|}
\hline \multirow[b]{2}{*}{$\begin{array}{c}\text { No } \\
\text {. }\end{array}$} & \multirow[b]{2}{*}{ Tahun } & \multirow[b]{2}{*}{$\begin{array}{l}\text { Jml. } \\
\text { Keg. } \\
\text { RKPD }\end{array}$} & \multirow[b]{2}{*}{$\begin{array}{l}\text { Jml. } \\
\text { Keg. } \\
\text { PPAS }\end{array}$} & \multicolumn{3}{|c|}{ Score Konsistensi } & \multirow[b]{2}{*}{$\begin{array}{l}\text { Score } \\
\text { Total }\end{array}$} & \multirow[b]{2}{*}{ Persentase } \\
\hline & & & & $\begin{array}{c}\text { Kegiatan } \\
\text { (nomenklatur) }\end{array}$ & $\begin{array}{c}\text { Pagu } \\
\text { indikatif } \\
\text { (Input) }\end{array}$ & $\begin{array}{c}\text { Indikator } \\
\text { kinerja } \\
\text { (Output) }\end{array}$ & & \\
\hline 1. & 2015 & 54 & 52 & 24 & 0,5 & 4 & 28,25 & $52,31 \%$ \\
\hline 2. & 2016 & 48 & 48 & 24 & 12 & 12 & 48,00 & $100,00 \%$ \\
\hline
\end{tabular}


Tabel 5. Rekapitulasi Score Konsistensi DPA terhadap RKPD

\begin{tabular}{|c|c|c|c|c|c|c|c|c|}
\hline \multirow[b]{2}{*}{ No. } & \multirow[b]{2}{*}{ Tahun } & \multirow[b]{2}{*}{$\begin{array}{c}\text { Jml. } \\
\text { Keg } \\
\text { RKPD }\end{array}$} & \multirow[b]{2}{*}{$\begin{array}{l}\text { Jml. } \\
\text { Keg } \\
\text { DPA }\end{array}$} & \multicolumn{3}{|c|}{ Score Konsistensi } & \multirow[b]{2}{*}{$\begin{array}{l}\text { Score } \\
\text { Total }\end{array}$} & \multirow[b]{2}{*}{ Persentase } \\
\hline & & & & $\begin{array}{c}\text { Kegiatan } \\
\text { (nomenklatur) }\end{array}$ & $\begin{array}{l}\text { Pagu } \\
\text { (Input) }\end{array}$ & $\begin{array}{c}\text { Indikator } \\
\text { kinerja } \\
\text { (Output) }\end{array}$ & & \\
\hline 1. & 2015 & 54 & 46 & 24 & 0,75 & 4 & 28,75 & $53,24 \%$ \\
\hline 2. & 2016 & 48 & 47 & 23,5 & 0,75 & 6,25 & 30,50 & $63,54 \%$ \\
\hline
\end{tabular}

rencana kerja pemerintah daerah. Untuk melihat apakah dokumen tersebut sudah dijadikan acuan atau belum perlu dilakukan analisis. Analisis dokumen dilakukan dengan mengetahui tingkat konsistensi kegatan antara dokumen RKPD dengan DPA tahun 2015-2016 seperti tabel 5 .

Dari tabel tersebut dapat diketahui bahwa tingkat konsistensi dokumen DPA terhadap RKPD tahun 2015 termasuk cukup yaitu sebesar 53,24\%. Hal ini menunjukan bahwa dokumen RKPD belum sepenuhnya digunakan sebagai acuan. Tingkat konsistensi DPA terhadap RKPD pada tahun 2016 mengalami kenaikan $10 \%$ menjadi sebesar $63,54 \%$ atau termasuk kategori cukup. Hal ini menunjukkan bahwa dokumen RKPD belum dijadikan acuan untuk penyusunan DPA SKPD. Faktor-faktor yang mempengaruhi konsistensi tersebut akan dijelaskan sebagai berikut:

Analisis Faktor yang Memengaruhi Konsistensi Perencanaan dan Penganggaran di Dinas Pariwisata

Berdasarkan analisis dokumen Renstra, Renja, RPJMD, RKPD, KUA PPAS, DPA di Dinas Kebudayaan dan Kepariwisataan menunjukkan adanya inkonsistensi. Inkonsistensi ini akan mempengaruhi outcome program dan sasaran yang dapat bermuara pada tidak tercapainya tujuan pembangunan daerah. Setelah dilakukan wawancara mendalam dengan partisipan dapat ditarik kesimpulan mengenai faktor-faktor yang mempengaruhi konsistensi pada Dinas Kebudayaan dan Kepariwisataan antara lain:

Kurangnya Pemahaman tentang Perencanaan dan Penganggaran

Untuk dapat mewujudkan konsistensi antara dokumen perencanaan dan penganggaran dibutuhkan pemahaman yang baik di tingkat SKPD. Perencana dan penangungjawab kegiatan di SKPD harus memiliki tingkat pemahaman yang baik dalam perencanaan dan penganggaran sehingga dalam merumuskan program dan kegiatan dapat konsisten dan sesuai jadwal yang sudah ditentukan. Pemahaman yang kurang baik akan menyulitkan dalam menyusun dokumen perencanaan. Dinas Kebudayaan dan Kepariwisataan karena nilai LAKIP masih C dan merasa belum baik dalam menyusun renstra akhirnya minta di bimbing oleh Tim dari Kementrian PANdan RB untuk menyusun renstra agar bisa baik dan lebih fokus.

Kurangnya pemahaman juga bisa menimbulkan multitafsir dalam menerjemahkan aturan sehingga menyebabkan tidak optimalnya kegiatan karena dijalankan oleh dua seksi sehingga sulit untuk mengevaluasi dan mengukur kinerjanya. Tahun 2015 di Dinas Kebudayaan dan Kepariwisa-taan masih ada satu kegiatan yang dijalankan oleh dua seksi sehingga belum sesuai dengan uraian tugas sehingga menyebabkan kesulitan dalam melakukan evaluasi kinerja nantinya. Ketidaksesuaian tugas dan kompetensi adalah masalah besar dan mengganggu implementasi sistem pengukuran kinerja, khususnya dalam upaya pencapaian kinerja (Sofyani \& Akbar, 2015).

SKPD Belum Memperhatikan Pagu Indikatif dan Indikator Kinerja

Sesuai dengan Permendagri 13 tahun 2006 dan permendagri 54 tahun 2010 bahwa dalam dokumen perencanaan dan penganggaran khususnya renja, RKPD dan DPA harus mencantumkan pagu indikatif dan indikator kinerja. Dengan demikian konsistensi diharapkan juga pada pagu indikatif dan indikator kinerja. Berdasarkan analisis data pada dokumen perencanaan dan penganggaran tahun 2015-2016 Dinas Kebudayaan dan Kepariwisataan terlihat kurang memperhatikan dalam hal pagu indikatif dan indikator kinerja terlihat dari banyak perubahan pada pagu indikatif dan indikator kinerja dalam dokumen yan dibandingkan. Hal tersebut dirasakan masih cukup sulit pemahaman di BKAD, Bappeda dan SKPD bahwa konsisten utamanya terletak pada program dan kegiatan meskipun ada perubahan anggaran ataupun indikator kinerja hal itu tidak dipersoalkan.

Hal ini menandakan bahwa SKPD belum memperhatikan terhadap pagu indikatif dan indikator kinerja, jika indikator kinerja berubah otomatis pagu juga berubah demikian pula sebaliknya jika pa- 
gu berubah atau dikurangi maka indikator kinerja juga akan berubah. Hal ini menandakan bahwa di tingkat SKPD pagu indikatif maupun indikator kinerja belum menjadi fokus utama dalam hal menjaga konsistensi perencanaan dan pengang-garan.

\section{Intervensi Politik anggota DPRD}

Pendekatan politik adalah salah satu dari empat pendekatan perencanaan yang diatur dalam perundang-undangan. Pendekatan politik dirumuskan oleh DPRD melalui pokok-pokok pikiran dewan. Namun seringkali hal ini tidak dimanfaatkan secara optimal oleh anggota dewan, seringkali pokokpokok pikiran diserahkan ke ekskutif terlambat atau tidak disusun secara lengkap. Hal ini menyebabkan anggota dewan terkadang membuat usulan yang mendadak karena tidak terwadahinya usulannya dalam pokok-pokok pikiran dewan. Seperti yang terjadi di Dinas Pariwisata, Komisi di DPRD Gunungkidul mengusulkan adanya Perda pemandu wisata seperti yang sudah dimiliki di Pemda DIY padahal hal itu tidak ada dalam dokumen renstra maupun renja, akhirnya hal itu batal dilaksanakan karena yang menjadi acuan Pemda DIY sendiri Perda pemandu wisata sudah terbit lama (10 tahun lebih) dan belum direvisi.

Intervensi politik masih terjadi dan diakui oleh anggota dewan, mekanisme yang seharusnya dilalui oleh DPRD yaitu musrenbang, pokok-pokok pikiran, KUA PPAS namun ada anggota dewan yang justru melalui cara lain yang tidak tepat seperti melalui rapat komisi dengan SKPD sehingga menyebabkan inkonsistensi dalam perencanaan dan penganggaran.

\section{Kebijakan Pemerintah Pusat/Provinsi}

Pemerintah pusat atau pemerintah propinsi terkadang membuat kebijakan yang munculnya tidak di awal waktu namun di pertengahan sehingga memengaruhi program/kegiatan yang sudah tersusun atau sudah ditetapkan. Pada Dinas Pariwisata pernah diminta menyusun renja untuk kegiatan tambahan yaitu Word Camping yang dipusatkan di Prambanan, Gunungkidul diminta menyiapkan untuk 800 orang pramuka di Nglanggeran, namun setelah melalui proses reviu Inspektorat dan pembahasan Tim Anggaran akhirnya kegiatan tersebut dianggarkan melalui Dinas Pendidikan.

Kebijakan dari pemerintah pusat maupun provinsi waktunya sering tidak bersamaan atau terlambat dengan proses perencanaan dan penganggaran daerah sehingga menyulitkan daerah ketika ada program/kegiatan yang akhirnya tidak bisa dijalankan karena kebijakan tersebut. Seperti pada Dinas Kebudayaan dan Kepariwisataan pada renja dan RKPD muncul anggaran untuk bidang kebuda- yaan namun dalam DPA kegiatan tersebut tidak muncul karena mendapat alokasi dari dana keistimewaan. Kebijakan tersebut juga bisa karena proyeksi penerimaan baik dari DAU, DAK yang tidak tepat menyebabkan penerimaan kurang sehingga harus mengurangi atau bahkan membatalkan kegiatan yang sudah direncanakan oleh SKPD.

Komitmen Pemangku Kepentingan, Pengambil Kebijakan dan Pelaksana Kegiatan

Dokumen perencanaan daerah disusun untuk memenuhi visi, misi dan tujuan pembangunan daerah. Dokumen tersebut akan tersusun dengan baik apabila ada komitmen dari pemangku kepentingan, pengambil kebijakan dan pelaksana kegiatan. Komitmen dari ketiganya sangat dibutuhkan agar perencanaan dan penganggaran itu dapat berjalan konsisten.

Komitmen pengambil kebijakan dibutuhkan untuk membuat kebijakan agar konsitensi perencanaan dan penganggaran semakin meningkat. Pelaksana kegiatan seringkali ditemui juga kurang komitmennya dalam menyusun rencana kegiatan. Dari analisis data terlihat dokumen RKPD disusun kurang rinci pada indikator kinerja berbeda dengan dokumen RKA yang tersusun rinci pada indikator kinerjanya. Komitmen legislatif sebagai pemangku kepentingan dalam bidang pariwisata juga sangat diperlukan, karena di tingkat legilatif peluang berubahnya kegiatan cukup besar. Hak budget yang dimiliki dewan sering kali dimanfaatkan oleh anggota dewan untuk melancarkan kepentingannya demi memenuhi janji politik kepada konstituennya. Hal ini dapat terlihat dari wawancara dengan salah satu anggota legislatif yang mengakui bahwa peru-bahan masih sering terjadi, terkadang sudah diputuskan di KUA PPAS namun pada saat rapat komisi dengan SKPD masih berubah lagi sehingga hal itu menyebabkan tidak konsisten.

\section{Proses Manual dalam Perencanaan}

Penyusunan dokumen perencanaan masih dilaksanakan secara manual. Aplikasi yang sudah ada adalah aplikasi SIPKD (Sistem Informasi Pengelolaan Keuangan Daerah) untuk penganggaran yang servernya ada di BKAD dan e monev untuk monitoring dan evaluasi yang servernya ada di Bappeda. Dengan proses manual perencana di masing-masing SKPD akan mengentry dua kali ke dalam dokumen perencanaan (yang masih manual) dan ke dalam penganggaran (yang sudah menggunakan aplikasi) sehingga akan membutuhkan banyak waktu dan memungkinkan terjadi human error karena banyaknya data yang di entry. Belum adanya aplikasi untuk perencanaan sehingga proses penyusunan doku-men untuk renja maupun RKPD masih 
manual tentu menyulitkan baik dari sisi perencana di masing-masing SKPD maupun yang melakukan kompilasi dalam penyusunan dokumen RKPD di Bappeda.

\section{Upaya Yang Dilakukan Pemerintah Daerah dalam Menjaga Konsistensi Perencanaan dan Pengang- garan.}

Berdasarkan hasil wawancara dan dari penelitian dokumen, pemerintah daerah telah melakukan upaya dalam rangka menjaga konsis-tensi perencanaan dan penganggaran daerah. Upaya tersebut dilakukan dengan membuat kebijakan maupun produk hukum berupa Perda atau Perbub untuk mendukung kebijakan tersebut. Beberapa upaya yang dilakukan untuk menjaga konsistensi perencanaan dan penganggaran antara lain:

\section{Inovasi PIWK (Pagu Indikatif Wilayah Kecamatan)}

Pagu Indikatif Wilayah Kecamatan mulai diterapkan di Gunungkidul sejak tahun 2013. Hal itu dilatarbelakangi karena usulan dari masyarakat dalam forum musrenbang desa maupun musren-bang kecamatan sangat sedikit yang terealisir. Hal itu kemudian mendorong Bappeda yang bekerjasama dengan LSM IDEA merancang sebuah kebijakan PIWK yang memberikan kepastian bahwa usulan dari masyarakat dalam musrenbang nantinya akan dianggarkan dalam APBD melalui DPA pada dinas terkait.

Rancangan kebijakan tersebut setelah melalui proses panjang akhirnya diterbitkanlah tiga peraturan yaitu: Peraturan Daerah Nomor 18 Tahun 2012; Peraturan Daerah Nomor 19 Tahun 2012 dan Peraturan Bupati Nomor 40 Tahun 2012 yang telah diperbarui dengan Peraturan Bupati Nomor 7 Tahun 2015. Dalam perda tersebut terdapat dua pagu yaitu Pagu Indikatif Sektoral (PIS) dan Pagu Indikatif Wilayah Kecamatan (PIWK). PIWK adalah sejumlah patokan batas maksimal anggaran yang diberikan berdasarkan wilayah kecamatan dan dilaksanakan oleh SKPD yang penentuan alokasi belanjanya ditentukan oleh mekanisme perencanaan partisipatif melalui mus renbang kecamatan dengan berdasarkan kebutuhan dan prioritas program.

Usulan masyarakat di bahas dalam musrenbang dan akan dipilih usulan yang menjadi prioritas dan memenuhi syarat untuk di masukan melalui PIWK berdasarkan pagu dari kecamatan tersebut. Selanjutnya usulan yang masuk PIWK akan masuk ke dalam renja dinas terkait dengan pagu dari PIWK yang akan ditambahkan ke pagu dinas. Perhitungan besaran PIWK untuk tiap-tiap kecamatan akan ditentukan dengan formula yang sudah diatur melalui Peraturan Bupati Nomor 7 Tahun 2015. Bupati menyampaikan rancangan PIWK kepada DPRD untuk dibahas bersama paling lambat minggu terakhir bulan desember dan nota kesepakatan paling lambat minggu pertama pada bulan Januari.

Pagu Indikatif Wilayah Kecamatan (PIWK) merupakan inovasi Pemerintah Kabu-paten Gunungkidul untuk meningkatkan kuali-tas perencanaan daerah sekaligus sebagai upaya men-jaga konsistensi usulan kegiatan dari masyara-kat akan dijamin untuk dapat dianggarkan dalam APBD. Dengan demikian, hal itu menunjukan adanya konsistensi bahwa pada kegiatan tertentu yang sudah di danai dengan PIWK tidak mengalami perubahan dari perencanaan sampai dengan penganggaran atau ditetapkan dalam APBD.

\section{Desk Renja oleh Bappeda}

Bappeda kabupaten Gunungkidul melaksanakan desk renja dengan mengundang perencana dari SKPD yaitu Kasubag Perencanaan dan Keuangan atau staf perencana. Pengertian deskrenja disini adalah duduk satu meja antara Perencana di SKPD dengan Tim Deskdari Bappeda untuk melakukan penelitian dokumen renja agar dapat disusun secara baik, konsisten atau tidak terjadi perubahan pada nomenklatur program dan kegiatan. Dalam proses desk juga dilihat apakah sudah sesuai dengan aturan dan juga program prioritas yang ada di RPJMD.

Bappeda dalam melaksanakan upaya untuk menjaga konsistensi dari dokumen dari Renja sampai kemudian tersusun RKPD melalui desk dengan meneliti apakah sudah mengacu pada renstra dan RPJMD. Dokumen RPJMD ke Renstra setidaknya pada level program harus sama. Kemudian dari renstra ke renja ataupun dari RKPD ke renja nomenklatur kegiatan juga tidak boleh berbeda.

\section{Desk RKA oleh Tim Anggaran}

Proses penyusunan RKA SKPD di Kabupaten Gunungkidul diawali setelah KUA-PPAS yang disampaikan Kepala Daerah disetujui oleh DPRD. TAPD menyiapkan rancangan surat edaran kepala daerah tentang pedoman penyusunan RKA-SKPD sebagai acuan kepala SKPD dalam menyusun RKA-SKPD. Berdasarkan Permendagri 13 Tahun 2016 Surat Edaran Kepala Daerah perihal pedoman penyusunan RKA tersebut diterbitkan paling lambat bulan Agustus tahun anggaran berjalan. Untuk penyusunan RAPBD 2016 Surat Edaran Bupati Gunungkidul tentang Pedoman Penyusunan RKA tahun 2016 diterbitkan tanggal 24 Agustus 2015 dan memberi tenggang waktu penyusunan RKA sampai dengan tanggal 25 September 2015. Dalam penyusunan RKA, SKPD menggunakan aplikasi SIPKD (Sistem Informasi Pengelolaan Keuangan Daerah). Aplikasi tersebut merupakan hibah dari Kemdagri yang bekerjasama dengan PT. Usadi Sistemindo Intermatika sebagai pengembang aplikasi. Setelah RKA disusun 
dan dikirimkan ke Bidang Anggaran BKAD, selanjutnya Tim Anggaran (TAPD) mengundang SKPD untuk melaksanakan Desk RKA. Dalam proses desk RKA TAPD akan mengecek doku-men RKA apakah program dan kegiatannya sudah sesuai dengan KUA-PPAS. Dalam proses penelitian ini Tim Anggaran Pemerintah Daerah (TAPD) me-ngacu pada program, kegiatan dan total pagu SKPD, untuk pagu masing-masing kegiatan masih bisa berubah sepanjang tidak melebihi pagu SKPD. Dalam desk, TAPD juga meneliti dokumen RKA apakah sudah cukup efektif dan efisien dengan me-ngacu pada Surat Edaran Bupati yang sudah diter-bitkan.

\section{Evaluasi Internal oleh Bappeda}

Sesuai dengan mekanisme yang diatur dalam Permendagri 54 Tahun 2010, bahwa Bappeda juga melaksanakan evaluasi perencanaan pembangunan daerah. Dalam hal Bupati akan melaksanakan konsultasi kepada Gubernur maka terlebih dahulu harus menyampaikan surat permohonan konsultasi dengan dilampiri salah satunya ialah hasil pengendalian dan evaluasi kebijakan perencanaan daerah. Dalam penyusunan RKPD sistematika penyusunan RKPD juga mencantumkan evaluasi RKPD tahun lalu. Pengendalian dan evaluasi perencanaan pembangunan daerah salah satu tujuan ialah untuk mewujudkan: Konsistensi antara RPJMD dengan RPJPD, Konsistensi antara RKPD dengan RPJMD dan keseuaian pembangunan daerah dengan indikator kinerja yang telah ditetapkan.

Bappeda Kabupaten Gunungkidul melakukan evaluasi terhadap dokumen perencanaan khususnya evaluasi hasil RPJMD dan evaluasi hasil RKPD. Dari dokumen yang didapat oleh peneliti di tahun 2015 terdapat dokumen yaitu evaluasi hasil RKPD semester II tahun 2015 dan evaluasi hasil RKPD semester II tahun 2016 kemudian evaluasi hasil RPJMD tahun 2010-2015. Evaluasi RKPD dilakukan bukan untuk kepentingan perubahan RKPD kedepan dan apakah hasil pelaksanaan renja sudah sesuai dengan RKPD. Evaluasi di Bappeda telah didukung dengan aplikasi berbasis online yaitu $e$ monev yang sudah diluncurkan di tahun 2016. Dalam aplikasi ini admin di SKPD akan melakukan entry untuk RKPD dievaluasi per triwulan sedang untuk RPJMD di evaluasi per tahun.

Pengawasan oleh Inspektorat Daerah

Inspektorat Daerah Kabupaten Gunungkidul telah melakukan pengawasan/reviu terhadap dokumen perencanaan dan penganggaran mulai tahun 2016. Reviu yang telah dilaksanakan tersebut antara lain: reviu RPJMD, RKPD, Renstra, Renja dan RKA. Dalam melakukan reviu Inspektorat daerah berpedoman pada Peraturan Menteri Dalam Negeri Republik Indonesia Nomor 18 Tahun 2016 Tentang
Pedoman Penyusunan, Pengendalian dan Evaluasi Rencana Kerja Pemerintah Daerah Tahun 2017. Selain itu juga berpedoman pada Peraturan Menteri Dalam Negeri Republik Indonesia Nomor 76 Tahun 2016 Kebijakan Pengawasandi Lingkungan Kementerian Dalam Negeri dan Penyelenggaraan Pemerintahan Daerah Tahun 2017.

Berdasarkan hasil penelitian, Inspektorat Daerah telah melakukan reviu terhadap dokumen perencanaan dan penganggaran. Reviu tersebut dilakukan dengan meneliti dan mengkroscek kesuaian dokumen perencanaan dan penganggaran seperti dokumen renja terhadap renstra, dokumen renstra terhadap RPJMD, dokumen renja terhadap RKPD ataupun dokumen RKA terhadap KUA-PPS atau RKPD.

Adanya proses reviu yang dilakukan oleh Inspektorat telah berhasil mengetahui adanya kegiatan yang tidak tercantum dalam KUA-PPAS dan akhirnya karena tidak ada dalam KUA-PPAS maka kegiatan tersebut dihapus. Berdasarkan Permendagri 18 Tahun 2016 dan Permendagri 76 Tahun 2016, Inspektorat Daerah melakukan pengawasan untuk penyelenggaraan pemerintahan 2017, namun sejak tahun 2015 Inspektorat Daerah telah melakukan pengawasan khususnya pada RKA untuk APBD 2016. Dengan pengawasan/reviu tersebut Inspektorat daerah telah berupaya menjaga konsistensi dokumen mulai dari perencanaan sampai penganggaran apabila numenklatur program dan kegiatan ada yang berubah maka Inspektorat Daerah akan membuat rekomendasi.

\section{Pengawasan oleh Inspektorat Daerah}

Inspektorat Daerah Kabupaten Gunungkidul telah melakukan pengawasan/reviu terhadap dokumen perencanaan dan penganggaran mulai tahun 2016. Reviu yang telah dilaksanakan tersebut antara lain: reviu RPJMD, RKPD, Renstra, Renja dan RKA. Dalam melakukan reviu Inspektorat daerah berpedoman pada Peraturan Menteri Dalam Negeri Republik Indonesia Nomor 18 Tahun 2016 Tentang Pedoman Penyusunan, Pengendalian dan Evaluasi Rencana Kerja Pemerintah Daerah Tahun 2017. Selain itu juga berpedoman pada Peraturan Menteri Dalam Negeri Republik Indonesia Nomor 76 Tahun 2016 Kebijakan Pengawasandi Lingkungan Kemen-terian Dalam Negeri dan Penyelenggaraan Pemerintahan Daerah Tahun 2017. Berdasarkan hasil penelitian, Inspektorat Daerah telah melakukan reviu terhadap dokumen perencanaan dan penganggaran. Reviu tersebut dilakukan dengan meneliti dan mengkroscek kesuaian dokumen perencanaan dan penganggaran seperti dokumen renja terhadap renstra, dokumen renstra terhadap RPJMD, dokumen renja 
terhadap RKPD ataupun dokumen RKA terhadap KUA-PPS atau RKPD.

Adanya proses reviu yang dilakukan oleh Inspektorat telah berhasil mengetahui adanya kegiatan yang tidak tercantum dalam KUA-PPAS dan akhirnya karena tidak ada dalam KUA-PPAS maka kegiatan tersebut dihapus. Berdasarkan Permendagri 18 Tahun 2016 dan Permendagri 76 Tahun 2016, Inspektorat Daerah melakukan pengawasan untuk penyelenggaraan pemerintahan 2017, namun sejak tahun 2015 Inspektorat Daerah telah melakukan pengawasan khususnya pada RKA untuk APBD 2016. Dengan pengawasan/reviu tersebut Inspektorat daerah telah berupaya menjaga konsistensi dokumen mulai dari perencanaan sampai penganggaran apabila numenklatur program dan kegiatan ada yang berubah maka Inspektorat Daerah akan membuat rekomendasi.

\section{Konsultasi dan Evaluasi Gubernur}

Badan Perencanaan dan Pembangunan Daerah melakukan konsultasi RPJMD kepada Gubernur berdasarkan pada pasal 69 Permendargi 54 Tahun 2010. Setelah dievaluasi dan ditindaklanjuti RPJMD yang telah ditetapkan dengan peraturan daerah kemudian menjadi acuan untuk penyusunan renstra SKPD. Untuk RAPBD proses evaluasi oleh Gubernur dilakukan setelah Bupati mengirimkan Peraturan Bupati tentang RKPD bersamaan dengan rancangan Peraturan Daerah tentang APBD (Pasal 132 Permendagri 54 Tahun 2010). RKPD yang telah ditetapkan digunakan sebagai bahan evaluasi rancanan Peraturan Daerah tentang APBD untuk memastikan bahwa APBD disusun berlandaskan pada RKPD (Pasal 133 Permendagri 54 Tahun 2010).

Pemerintah Kabupaten Gunungkidul melakukan hal ini sebagai amanat peraturan perundangan dan juga sebagai upaya konsultasi apabila ada halhal yang dianggap kurang pas dengan peraturan perundangan seperti perubahan yang dilakukan atas usul DPRD.Evaluasi Gunernur menjadi salah satu upaya untuk menjaga konsistensi antara dokumen perencanaan dan penganggaran. Hal ini dilakukan misalnya seperti ketika DPRD punya usulan yang tidak sesuai dengan dokumen KUA-PPAS maka evaluasi Gubernur dapat menjadi jalan terakhir ketika proses evaluasi internal oleh Bappeda atau reviu Inspektorat tidak berhasil.

Penelitian terdahulu Fitry (2012), meneliti konsistensi perencanaan dan pengang-garan daerah khusus bidang kesehatan, kemudian Sugiarto dan Mutiarin (2016) melakukan penelitian tentang konsistensi perencanaan pembangunan daerah dengan anggaran daerah khusus pada bidang fisik dan prasarana dan Kumalasari (2016) melakukan penelitian tentang konsistensi antara dokumen RKPD, PPAS serta APBD. Jadi, penelitian ini melengkapi penelitian terdahulu karena penelitian terdahulu belum ada yang meneliti tentang konsistensi di bidang pariwisata yang merupakan salah satu penopang utama pendapatan daerah. Penelitian terdahulu meneliti terbatas mengenai faktor-faktor yang mempengaruhi konsistensi sehingga penelitian ini melengkapinya, dengan meneliti faktor-faktor yang mempengaruhi konsis-tensi juga meneliti upaya apa yang dilakukan dalam meningkatkan konsistensi perencanaan dan penganggaran daerah.

\section{SIMPULAN}

Berdasarkan hasil analisis data yang telah dilakukan, maka dapat diambil kesimpulan khususnya pada dokumen RKPD dengan DPA di Disbudpar tahun 2015-2016 yaitu: Tingkat konsistensi RKPD dengan DPA Bidang Pariwisata Disbudpar tahun 2015 sebesar 53,24\% (cukup) dan tahun 2016 naik menjadi 65,54\% (baik). Dokumen tersebut merupakan dokumen utama sehingga dapat dikatakan tingkat konsistensi perencanaan dan penganggaran belum optimal. Untuk tingkat konsistensi dokumen yang lain sebagai berikut: 1) Tingkat konsistensi RPJMD dengan Renstra 2010-2015 (tahun 2015) sebesar 88,89\% (sangat baik) dan RPJMD dengan Renstra 2016-2021 (tahun 2016) naik menjadi sebesar 100\% (memuaskan); 2) Tingkat konsistensi kegiatan pada renstra dan renja tahun 2015 sebesar 85,71\% (sangat baik) dan tahun 2016 naik menjadi sebesar 97,87\% (memuaskan); 3) Tingkat konsistensi kegiatan pada RKPD dan PPAS tahun 2015 sebesar 52,31\% (cukup) dan tahun 2016 naik menjadi sebesar 100\% (memuaskan); 4) Tingkat konsistensi kegiatan pada RKPD dan DPAtahun 2015 sebesar 53,24\% (cukup) dan tahun 2016 naik menjadi sebesar 63,54\% (baik)

Berdasarkan hasil analisis data baik dari wawancara maupun dari dokumen perencanaan dan penganggaran yang telah dilakukan tidak optimalnya tingkat konsistensi dokumen terjadi pada tahapan penyusunan dokumen RAPBD yaitu dokumen RKPD, PPAS dan APBD (DPA SKPD). Tahap ini memang rentan terhadap perubahan. Faktor-faktor yang mempengaruhi konsistensi dokumen perencanaan dan penganggaran di Dinas Kebudayaan dan Keariwisataan antara lain: Kurangnya pemahaman tentang perencanaan dan penganggaran, baik di tingkat ekskutif maupun legislatif; Intervensi politik anggota DPRD; Komitmen pemangku kepentingan, pengambil kebijakan dan pelaksana kegiatan; Kebijakan pemerintah Pusat atau Provinsi yang kadang terlambat; SKPD belum memperhatikan pagu indikatif danindikator kinerja; Proses manual dalam perencanaan.

Upaya yang dilakukan oleh Pemerintah Daerah dalam menjaga atau meingkatkan konsis- 
tensi perencanaan dan penganggaran daerah antara lain: Inovasi PIWK (Pagu Indikatif Wilayah Kecamatan); Desk Renja oleh Bappeda; Desk RKA oleh Tim Anggaran; Evaluasi Internal oleh Bappeda; Pengawasan oleh Inspektorat Daerah; Konsultasi dan Evaluasi Gubernur.

Berdasarkan kesimpulan dari penelitian di atas, maka ada beberapa rekomendasi yang dapat peneliti sampaikan untuk meningkatkan konsistensi perencanaan dan penganggaran antara lain: (1) Pemberian penghargaan terhadap kabupaten/kota dengan perencanaan terbaik perlu dipertahankan memacu kabupaten/kota agar selalu meningkatkan perencanaan daerahnya; (2) Mengadakan pelatihan perencanaan dan penganggaran daerah untuk meningkatkan pemahaman perencana di masingmasing SKPD dan workshop/lokakarya dalam upaya meningkatkan kulitas perencanaan dan penganggaran daerah; (3) Bupati atau Sekretaris Daerah dapat membuat surat permohonan kepada DPRD agar pokok-pokok pikiran dewan yang bersumber dari aspirasi konstituen untuk dibuat lebih awal sehingga dapat dimasukan dalam RKPD; (4) Pemerintah Propinsi dalam mengevaluasi RKPD, KUAPPAS dan APBD untuk dapat memberikan ruang konsultasi sehingga apabila ada program/kegiatan yang tidak konsisten dalam dokuemen perencanaan dan penganggaran dapat memberikan pengarahan untuk membatalkan program/kegiatan tersebut; (5) Menggunakan aplikasi perencanaan dan penganggaran yang dapat diintegrasikan sehingga memudahkan bagi perencana di SKPD maupun di Bappeda.

Penelitian ini memiliki keterbatasan antara lain: Penelitian hanya dilakukan di Dinas Pariwisata sehingga belum dapat memberikan gambaran secara menyeluruh mengenai faktor-faktor yang mempengaruhi konsistensi perencanaan dan penganggaran daerah di Kabupaten Gunungkidul.

Penelitian ini dapat dijadikan bahan kajian baik di Kabupaten Gunungkidul atau daerah lain untuk memahami seluk beluk permasalahan mengenai konsistensi perencanaan dan penganggaran sehingga memudahkan untuk mengambil kebijakan dalam meningkatkan konsistensi perencanaan dan penganggaran. Penelitian ini juga dapat dijadikan referensi bagi penelitian selanjutnya dengan meneliti bidang yang berbeda yang akan memperkaya literatur akademis yang bermanfaat bagi pembacanya.

\section{DAFTAR PUSTAKA}

Creswell, J.W. (2014). Research Design: Qualitative, Quantitative, and Mixed Methods Approaches Edisi Keempat. California: SAGE Publications.

Fitry, R. (2010). Analisis Konsistensi Perencanaan dan Penganggaran Bidang Kesehatan Kota
Lubuklinggau Tahun 2010. Tesis: Universitas Indonesia.

Halim, A. \& Bawono, I., R. (2011). Pengelolaan Keuangan Negara-Daerah: Hukum, Kerugian Negara, dan Badan Pemeriksa Keuangan. Yogyakarta: UPP STIM YKPPN.

Peraturan Bupati Kabupaten Gunungkidul Nomor 40 Tahun 2012 tentang Tata Cara Perhitungan Pagu Indikatif Wilayah Kecamatan dan Penyusunan Program Pembangunan Prioritas.

Peraturan Daerah Kabupaten Gunungkidul Nomor 12 Tahun 2012 tentang Tata Cara Penyusunan Rencana Pembangunan Daerah dan Pelaksanaan Musyawarah Pembangunan Daerah.

Peraturan Menteri Dalam Negeri Nomor 54 Tahun 2010 tentang Pelaksanaan Peraturan Pemerintah Nomor 8 Tahun 2008 Tentang Tahapan, Tatacara

Penyusunan, Pengendalian, Dan Evaluasi

Pelaksanaan Rencana Pembangunan Daerah.

Peraturan Pemerintah Nomor 8 Tahun 2008 Tentang Tahapan, Tata Cara Penyusunan, Pengendalian dan Evaluasi Pelaksanaan Rencana Pembangunan Daerah.

Sofyani, H., \& Akbar, R. (2015). Hubungan Karakteristik Pegawai Pemerintah Daerah dan Implementasi Sistem Pengukuran Kinerja: Perspektif Isomorfisma Institusional. Jurnal Akuntansi dan Auditing Indonesia (JAAI), Vol.19, No. 2

Sugiarto, A. \& D. Mutiarin. (2016). "Konsistensi Perencanaan Pembangunan Daerah dengan Anggaran Daerah (Sudi Kasus Pada Proses Musyawarah Perencanaan Pembangunan Daerah, Rencana Kerja Pembangunan Daerah, dan Anggaran Pendapatan Belanja Daerah Bidang Fisik dan Prasarana Tahun Anggaran 2013-2015 di Kabupaten Gunungkidul)”.

Tesis: Yogyakarta: Universitas Muhammadiyah Yogyakarta.

Undang-Undang Republik Indonesia Nomor 17

Tahun 2003 Tentang Keuangan Negara.

Undang-Undang Republik Indonesia Nomor 23

Tahun 2014 Tentang Pemerintahan Daerah.

Undang-Undang Republik Indonesia Nomor 25

Tahun 2004 Tentang Sistem Perencanaan

Pembangunan Nasional. 